Article

\title{
The Mission-Oriented Approach for (Cross-Border) Regional Development
}

\author{
Francesco Cappellano ${ }^{1, *}$ (i) and Joanna Kurowska-Pysz ${ }^{2}$ (]) \\ 1 Karelian Institute, University of Eastern Finland, 80101 Joensuu, Finland \\ 2 The Research Institute on Territorial and Inter-Organizational Cooperation, Faculty of Applied Sciences, \\ WSB University, 41-300 Dąbrowa Górnicza, Poland; jkurowska@wsb.edu.pl \\ * Correspondence: Francesco.cappellano@uef.fi
}

Received: 15 May 2020; Accepted: 23 June 2020; Published: 25 June 2020

\begin{abstract}
During the times of the COVID-19 pandemic, nations have issued unprecedented border closures around the world, yielding abrupt impacts on the movement of goods and people. This has heavily affected the quality of life in border regions, which are often found to be at a disadvantage when compared to other regions in terms of employment, accessibility, social services and economic growth. Based upon developing threads in the literature concerning the untapped potential for development in border regions, we argue that the Mission-Oriented Approach (MOA) can fit well with the ambitious goal to revitalize those territories in the aftermath of the pandemic. Despite the surge of MOA in discourses on innovation policy, we seek to implement it in a regional development perspective, pursuing both economic and social policy objectives. The authors unravel the policy concept of MOA into three main aspects: (I) address a sound societal challenge; (II) Research \& Development (R\&D) regional agenda embedded in a cross-border regional development vision; (III) mobilizing multiple cross-sectorial projects. Through a desk study analysis, the authors draw insights from selected case studies where these aspects have been implemented to inspire policy intervention in the aftermath of COVID-19. This paper presents the MOA theoretical model, which has potential explanatory power in other cross-border regions.
\end{abstract}

Keywords: mission-oriented approach; regional policy; border regions; place-based approach; COVID-19; innovation policy

\section{Introduction}

The COVID-19 pandemic has led nations to issue unprecedented border closures around the world, resulting in abrupt impacts on the movement of goods and people. This has heavily affected global value chains, halting economies around the world. For the time being, it is difficult to forecast the duration and the magnitude of the global recession that has just started. The pandemic has brought to the fore the issue of border management as a trending topic in the policy arena. The border regions are often found to be at a disadvantage when compared to other regions in terms of employment, accessibility, social services and economic growth. Here, the quality of life has been heavily affected by the border closures, where they are experiencing an economic loss and a threat to the public service provision mechanisms that rely on cross-border flow of people and goods. Nonetheless, all policy makers are concerned with ensuring a stable and steady economic rebound after this healthcare emergency. Therefore, the research problem is to find an appropriate policy to ignite economic recovery, social cohesion and environmental protection in cross-border regions in connection with the sustainable development goals.

In this regard, we discuss how the Mission-Oriented Approach (MOA) can be implemented in cross-border regions to revitalize these territories in the aftermath of this COVID-19 outbreak. 
Mission-oriented policies are usually driven at the national level, as they channel large investments towards R\&D activities. Therefore, the authors attempt to illustrate the rationale to adopt this innovation policy concept, translating it into a local economic development perspective and finally applying it to the cross-border regions, defined as "bounded territorial units composed of the territories of authorities participating in Cross-Border cooperation" [1]. The high "directionality" to be adopted throughout the mission-design phase, and the sharp "intentionality" recommended during mission implementation, can represent key characteristics to effectively address the complex issues at stake in border regions. Furthermore, the authors take into consideration previous innovation policies so as to illustrate the added value proposed by the MOA within the framework of (cross-border regional) development. In fact, the MOA combines a sharp policy orientation to address challenges together with a sound impact at a societal level. At the same time, cross-border regions are seen to be a suitable test-bed for implementing MOA at a regional level. To illustrate its implementation, the analysis is based on real-case evidence from illustrative cross-border regions. The analytical framework is based on three critical issues concerning MOA practical set-up, evidenced in the literature review, including policy mix, governance [2] and a bottom-up engagement. Whilst, the case studies have been selected through three main criteria that distinguish MOA from other approaches: (I) address a challenge with a sound societal value; (II) alignment between R\&D regional agenda and a cross-border regional development vision; (III) mobilizing multiple projects in a cross-sectorial perspective so as to revitalize cross-border regions. Furthermore, the authors chose regions where research activities have been conducted in the recent past to ensure the richness of in-depth knowledge of the cases, along with the widely studied Øresund as a benchmark of a "textbook" example of cross-border integration.

The case study analysis methodology has been selected to discuss how particular aspects have been managed in cross-border regions. This will give the readers real evidence on current practices, which can be further integrated into the holistic mission-oriented approach mobilized in cross-border regions. The data were collected through desk research analysis, including formal cooperation agreements, academic papers, newspaper articles and official documents on cross-border cooperation in the selected regions.

The main purpose of this paper is to advance the existing state-of-art upon two trajectories: (I) unfold crucial aspects concerning MOA implementation; and (II) showcase concrete examples of what regional policies in cross-border regions have been doing with regards to the three main elements of MOA hereby discussed. All in all, the research works as an evaluation of current practices, but it can be adapted in the near-term future when the border regions will need to harness a post-pandemic strategy.

The results reinforce the need to adopt a "place-based" approach when implementing MOAs, as the cases illustrate that cross-border regions have been designing their strategies upon their key assets in the R\&D domains. The governance scheme reflects that the North American cases succeeded in engaging private stakeholders, which are found to promote a cross-border initiative with high societal value (e.g., war on cancer), while in Europe, the partnerships are driven by public authorities. The Italian-Slovenian cross-border region showcases an innovative framework to channel EU-funded projects through integrated territorial investments (ITIs). More research is needed to understand the congruity of MOA in other cross-border regions, as well as the applicability and the impacts of regional-based MOA in a post-pandemic scenario.

\section{Theoretical Background}

\subsection{Overview of the Mission-Oriented Approach}

The mission-oriented approach relies on the stance that "Big Science" should be deployed to tackle big problems [3]. Accordingly, the mission-oriented policies can be considered as "systemic public policies that draw on frontier knowledge to attain specific goals" [4] (p. 804). Throughout the panorama of innovation policies, mission-oriented policies have been ranked as a "transformative innovation policy" with a narrow focus on innovation processes to connect innovation policy with 
societal challenges and transformative change [5]. In contrast with previous policy approaches focusing on the "rate" of innovation, mission-oriented policies place emphasis on the "direction" to pursue [6]: defining clear technological, social, environmental or industrial objectives [7]. This is now more viable since "more recently, the long-run goal of transforming the economy to sustainability has become broadly accepted" [8]. Being cross-sectoral in nature, mission-oriented policies cannot be considered sectoral policies. In fact, the MOA rationale is to get many sectors working together towards the development of specific technologies in line with goals defined at a country or state level: missions [9]. Accordingly, the mission-oriented approach does not support a "horizontal approach" to foster a systemic attitude to spread innovation. At the same time, mission-oriented policies champion a "non-neutral" attitude [7] by carefully selecting the economic sectors to target in connection with the objectives of missions.

The need and legitimacy of "selection" is not new in the industrial policy discussion, as implicitly linked to the need to "discover" new activities through a wider effort to re-structure the economy [10]. The salience of "priority selection" was embedded in the Smart Specialization Strategy (S3) [11], which has been spearheading innovation policies in Europe since 2014. The S3 concept encourages to re-think regional policy in terms of expenditure accountability, envisaging a result-oriented approach driven by objectives, goals and strategies (McCann and Ortega-Argiles, 2014). MOA adds to this the need to orient R\&D objectives towards societal challenges (e.g., the Sustainable Development Goals). By doing so, MOA allows policy makers to mobilize sectors "unrelated" one another [12].

The MOA rationale relies on an innovative consideration of the role of the public sector, which is widely advocated by Mazzucato [13], to abandon the neoliberal concept of a "market-fixer" role and exert a "market-shaper" attitude, choosing a direction (priorities to address through the MOAs) and pursuing it with high intentionality. To explain this, Mazzucato recalls that major scientific breakthroughs (such as the birth of the Internet) were all prompted by massive public R\&D investments through public agencies (as a textbook example of missions: the Apollo program, which pursued the objective to land a man on the moon).

The main elements of mission-oriented policies include:

- Having an ambitious nature and addressing societal value;

- Pursuing a clear direction: targeted, measurable and time-bound;

- Involving research and innovation: technological readiness over a limited time frame;

- Being cross-sectoral, cross-actor and cross-disciplinary;

- Involving multiple competing solutions and bottom-up experimentation [14].

While MOA has been profoundly debated and is considered innovative and reliable to be embraced by the EU Horizon Europe during the upcoming programming period of 2021-2027 [15], MOA implementation into real policy is not a straightforward task. A report for the European Commission considered several case studies disclosing heterogeneous mission-oriented policies in terms of scale, policy mixes adopted, governance structures and technological objectives pursued [16].

The high extent of the flexibility of this policy can harm effective implementation, transferring much freedom (and responsibility) to policy makers [8]. This is even truer when government structures rely on authority-based and high-level bureaucratic agencies, which then force the missions to rely on countries' developmental state legacies [17]. Mission-oriented policies feature a very high level of flexibility envisaged by the main scholars, which undermines the delivery of prescriptions for their implementation. Thus, it is found that mission-oriented policies do not follow homogenous implementation, but they can be divided in two main groups-accelerators and transformers (see Table 1)—even if several missions can pursue a hybrid approach. 
Table 1. Definitions of transformer and accelerator groups.

\begin{tabular}{ccc}
\hline Focus & $\begin{array}{c}\text { Achieving a Transformative } \\
\text { Change }\end{array}$ & $\begin{array}{c}\text { Accelerating the Technological } \\
\text { Development }\end{array}$ \\
\hline Objective & $\begin{array}{c}\text { Address complex problems } \\
\text { requiring systemic transformation } \\
\text { (e.g., climate change) }\end{array}$ & $\begin{array}{c}\text { Ambitious yet defined goals (e.g., man on the } \\
\text { moon, war on cancer). }\end{array}$ \\
\hline Means & $\begin{array}{c}\text { R\&D, change in regulations and } \\
\text { user behaviors. }\end{array}$ & $\begin{array}{c}\text { R\&D, mechanisms to allow higher risk-taking } \\
\text { and the sharing of benefits. }\end{array}$ \\
\hline
\end{tabular}

Adapted from Fisher et al., 2018 [16].

Either the transformer or the accelerator MOA requires a governance structure that should be flexible to balance bottom-up and top-down approaches. At the same time, it should be reflexive to self-monitor and adopt ongoing adjustments on the basis of progress made and the changing technological and market dynamics to reach their final goals [16]. MOA requires a rigid alignment between different layers of decision-making (EU, national and regional authorities), but also broad bottom-up engagement to achieve legitimization and awareness on the mission focus at stake.

Mission-oriented policies are usually driven at a national level, as they channel large investments towards R\&D activities. This is the case of publicly funded programs in the US targeting three main sectors: agriculture, defense and health [18]. Focusing on these mission-oriented programs, Mowery et al. (2010) discussed their implication in terms of gains and losses, disclosing who benefits from each program - public agencies in the case of defense R\&D investments, private farmers for agricultural programs [18] —and unveiling the unintended consequences of MOAs. This is the case with manifold technological "spin-offs" surging in the aftermath of defense R\&D investments. In the same vein, Mazzucato $[4,12]$ recommends to also consider any unforeseen or unintended impacts when "weighting" the value of mission-oriented policies. For instance, the Apollo mission contributed to the development of the Internet. When talking about outcomes, Fisher et al. [16] concluded their analysis acknowledging that MOA can yield tangible results in scientific outcomes in the short term in the form of new knowledge produced (either in terms of publications or technologies); but in the long-term, they warn that several MOAs failed to reach their targets in the expected time frame. Furthermore, mission-oriented policies are empirically proven to stimulate tangible results from a macro-economic perspective: larger effect on GDP and a stronger allure (e.g., "crowd-in effect") of private investments over generic public expenditure [19].

\subsection{Why the Mission-Oriented Approach Matters in Cross-Border Regions}

MOA gave birth to an industrial policy concept that can be applied to technological challenges in cross-cutting domains with ample societal value, including the medical field (war on cancer), aerospace (man on the moon) energy transition ("EnergieWende") or environment protection (clean oceans). The concept is also valuable in a (cross-border) regional development perspective pursuing goals with significant territorial impacts—-such as the Green growth, considered in past missions [16] only at a national level.

In our rationale, MOA represents a valuable solution to endanger transformative change in cross-border regions bouncing back in the aftermath of the COVID-19 pandemic. The high "directionality" to be adopted throughout the mission design phase, and the sharp "intentionality" recommended during mission implementation, can represent key characteristics to effectively address the complex issues at stake in cross-border regions [20]. We shall now elaborate upon the three main reasons to explain the congruity of MOA with the needs of these areas.

Firstly, the salience of MOA grows, since it bolsters technological advancements that fit well with the growing role of cross-border regions in global value chains. Over the last few decades, a couple of North American cross-border regions have been surging in their prominence as tech hubs, particularly on the Pacific Coast [21-23]. In the European context, the Swedish-Danish Øresund region gained 
importance as a biotech cluster with global resonance [24], also due to its landmark cross-border bridge. From the perspective of social scientists, the cross-border regions are seen as favorably positioned for reaping the benefits of innovation economies [25-27]. The (in)tangible capital of places as combined knowledge (generated or attracted) [22], local networks [21] and the physical proximity to the border [28,29] explain why cross-border regions are proven to be a source of innovation [30], yet they are unexploited [31]. However, we bear in mind that innovation policies applied in these regions do not represent a novelty per se in regional studies. The Cross Border Regional Innovation System (CBRIS) [32] represents the adaptation of the regional innovation system to a cross-border regional context. Moreover, the CBRIS works as an evaluative framework to assess the potential (and the current stage) of innovation system development in border region contexts.

The region of Galicia-North Portugal has developed a cross-border strategy [33], which then allowed the local European Grouping of Territorial Cooperation (EGTC) to steer the Smart Specialization Strategy of Galicia and Northern Portugal (RIS3T) as the first cross-border research and innovation strategy in the EU. The RIS3T tailors an R\&D agenda to the specificities of this Spanish-Portuguese cross-border region to generate economic knowledge, quality employment and social welfare by jointly promoting their strengths and common challenges. Similarly, adopting a mission-oriented approach, the border regional policies can pursue a direction for innovation and development, which can be assumed as a territorial vision for joint development but also as a "space" for specialization in terms of economic sectors. It can be a real catalyst for these regions' smart development [34].

Secondly, MOA combines a sharp policy orientation to address challenges with a sound impact at a societal level. Therefore, MOA adds to the table the aim to address specific problems in cross-border regions under a clear direction within a time-bound framework with a relevant societal value [16]. Besides being heavily innovation-led, MOA focuses "not on technological challenges alone, but rather on areas traditionally falling under public services, such as the education or welfare state, and entails changes across various economic and policy sectors" [14]. This seems to fit well with the needs of cross-border regions, which span across welfare and social needs, including transportation, health, education services and economic development, as heralded in the last European Spatial Planning Observatory Network (ESPON) State of European Territory report [35].

Thirdly, cross-border regions offer a suitable test-bed for implementing the mission-oriented approach, considering:

- The high-technological solutions implemented in border management as security controls to patrol the border and to verify the identity of passengers and freight passing through customs [36];

- The complexity of inter-related societal challenges occurring in cross-border regions requires bold commitments to lead tangible impacts;

- The sense of "identity", which bonds residents, commuters and workers in border communities together, distinguishes them from their countrymates, preparing the ground for a collectively shared vision for change;

- The perception of being remote and detached from the rest of their country pushes border societies to work proactively together to find solutions with a certain autonomy. This increases the likelihood of embracing bold and radical breakthroughs;

- Border communities rely on local (institutional) networks abiding from the central agencies-led policies.

\section{Materials, Methods and Results}

This paper aims at informing policy recommendations concerning the potential implementation of mission-oriented policies in border regional contexts. Therefore, the authors provide real-case evidence from illustrative case studies. The literature review illuminates three critical issues when considering the adoption of MOA at a regional level, which will form the analytical framework to investigate the cases. As illustrated in the next sections, we discuss how MOA can be translated from innovation 
policy to a potential guide for territorial development. Accordingly, we define three main elements that distinguish MOA from other approaches. These will be used as criteria to select the case studies.

\subsection{Research Strategy}

After discussing the theoretical potential of MOA to effectively address border regional contexts, we then unfold the research question of this paper concerning the translation of MOA into a cross-border regional development strategy. To date, there has been no practical implementation of mission-oriented policies in this field, despite their potential discussed in the previous section. Thus, our contribution explores MOA implementation, outlining concrete examples from three illustrative cross-border regions.

As they rely on large R\&D investments, MOAs are often mobilized at a national level, but there is a need to translate them into spatially-oriented local development policies under a more "place-based" approach [37]. Accordingly, we consider three aspects particularly relevant in the implementation phase of MOAs, which deserve to be clarified.

\subsubsection{MOA Policy Mix}

The implementation of MOAs seems to be flexible as well as very case-sensitive. This impedes the releasing of general prescriptions on the implementation of MOA, particularly in the case of policy mix. The policy mix is considered as a "portfolio of instruments [..] strategically used to affect the directionality of innovation, fostering a structural transformation of the economy through experimentation" [38] (p. 3). There is a large consensus that MOAs should rely on complex and flexible policy mixes that should go beyond large $R \& D$ investments, but there is no real prescription in this regard. Furthermore, the policy mix should also tackle non-technological barriers (e.g., regulation, standards, user and societal acceptance), which are proven to play a crucial role in the success of transformative missions [16]. Accordingly, Mazzucato [6] also encourages the fostering of innovation in the policy domain (e.g., "policy-making"), endorsing the creation of new instruments suitable to reward business in manifold sectors mobilized through MOAs or advocating the shift "from static subsidies to dynamic [public] co-investments" (p. 7) funded by the EU and its Member States.

In the same vein, the report released by Fisher et al. (2018) outlines that a majority of respondents (60\%) prefer "non-prescriptive" and flexible policy instruments to pursue missions. At the same time, greater freedom to identify instruments (and their budgets) questions the accountability of public expenditure and its coherence with the objectives, which are found to be contradictory even within the same MOA [16].

In the MOA narrative, it is recommended to adopt actions working on both the demand and supply sides [6]. The case of the Austrian Active Assisted Living (AAL) program, intended to tackle the needs of the aging population as a societal challenge, was found to adopt a policy mix relying on supply-side instruments only, including financial support, non-financial support and commercialization activities [16]. In this regard, public procurement is considered a tool to ignite innovation by triggering the demand for new products-which do not exist yet-in order to fulfill the interrelated and sophisticated needs [39] of societal challenges that are not necessarily known [40]. At the same time, public procurement has been reported to be weakly effective in accelerating systemic change [16].

The instance of the Greater Manchester Region (UK), which embraced the Mission for Carbon Neutrality of the City by 2038, showcases a number of hypothetical projects that should emerge from ideal participative co-design processes through community engagement practices. This mission-oriented strategy is designed to leverage projects in manifold sectors, including manufacturing and material, digital and media, construction, transport, health, energy, education and environment [12]. 


\subsubsection{Bottom-Up Engagement}

Bottom-up engagement strategies also represent a very quickly described chapter in the MOA narrative. While quietly envisaged, it is hard to think that solely postulating a challenge with high societal value will automatically lead to inclusive community engagement. Fisher et al. (2018) conclude there is "no clear picture" concerning citizens' roles despite it being highly advocated [16]. Accordingly, their report summarizes the impact that citizen engagement in the implementation of mission-oriented $R \& D$ initiatives is often found (at roughly $50 \%$ ) to yield neutral or (highly) negative impacts. On the other hand, the instance of the German "Energiewende" - a transition of the national energy supply to natural resources-has been prompted by a niche grass-roots movement.

\subsubsection{Governance}

In MOA, the priorities should be defined at a country or state level, but then the creation of high engagement with multiple stakeholders is needed. There is still much to investigate concerning whether this decision-making process should yield "open-policy making", including different levels of governance or limitation of the participation process to mere "tokenism".

These three issues will be used to form the analytical framework to guide our case study analysis. This methodology has been selected to discuss how particular aspects have been managed in cross-border regions. This will give to the readers real evidence on current practices that can be further integrated into a holistic mission-oriented approach mobilized in cross-border regions. The data were collected through desk research analysis, and equally case studies connected with interviews. The authors selected a number of case studies highlighting where the regional authorities considered one of these aspects in shaping their approach concerning cross-border regional development. The cases are collected from a broad spectrum, both in North American and in European contexts. To guide our analysis, we unravel the MOA concept in three main aspects reported below (Table 2).

Table 2. Case study selection upon the criteria investigated

\begin{tabular}{cc}
\hline CRITERIA & CASE STUDY \\
\hline Address a challenge with a sound societal value & Pacific Northwest across the US and Canada \\
\hline $\begin{array}{c}\text { Alignment between the RED regional agenda and a } \\
\text { cross-border regional development vision }\end{array}$ & Swedish-Danish Øresund region \\
\hline $\begin{array}{c}\text { Mobilizing multiple projects in a cross-sectorial } \\
\text { perspective to revitalize the cross-border region }\end{array}$ & Region across Italy and Slovenia \\
\hline
\end{tabular}

\subsection{Case Study Review}

The case studies are not hailed here as best practices, but they are found relevant to enlighten the mentioned aspects as part of further MOA implementation in a cross-border regional context. The authors drew information from a thorough case study analysis based on activities on desk. However, a more in-depth analysis might complete this information, even though the abundance and accuracy of information gathered does not need data triangulation.

\subsubsection{The War on Cancer in Cascadia}

In the Pacific Northwest region between the US state of Washington and the Canadian British Columbia province, a public-private initiative-the Cascadia Innovation Corridor-has been catalyzing the efforts to connect and enhance both regions and create exciting new opportunities for young people and underserved populations [41] since 2016. The Cascadia Innovation Corridor (CIC) promotes the vision to bolster the region's key assets and promote it as a global hub for innovation. This vision is based in a cross-sectoral perspective, including sectors where the cross-border region possesses competitive advantages, most notably life sciences, transportation and transformative technology. Therefore, the CIC seeks to mobilize its R\&D assets to spur economic growth on both sides of the 
border. It combines the research agenda with a vision for territorial development centered around a high-speed train, which will link the main cities throughout Cascadia [42,43].

Supported by Washington tech giants (most notably Microsoft and Amazon), the local public authorities have been part of the CIC with different engagement degrees per government levels [42]. A "secretariat" drives the cross-border regional development agenda in Cascadia. Oncology, as part of the life science sector, is one of the fields where the region possesses competitive R\&D capacities and strong ties among actors across the border. In fact, the Fred Hutchinson Cancer Research Center (based in Seattle) and the British Columbia Cancer Agency (based in Vancouver, BC) share a long-lasting collaboration in this field, based on researchers from both sides of the border working closely together. The two institutions signed a Memorandum of Understanding (MoU) to formalize their cooperation, which has been yielding remarkable outcomes (most notably, a jointly produced patent covered by intellectual property rights) activating a hectic mobility of researchers from the two agencies [43]. Resting on these solid bases, the Richmond-based tech giant Microsoft earmarked $\$ 4$ million to accelerate cancer research through the Cascadia Data Discovery Initiative (CCDI), which gathers together the Fred Hutchinson Cancer Research Center, the University of Washington eScience institute and the Knight Cancer Institute at Oregon Health and Science University from the US side. The British Columbia Cancer Agency and the University of British Columbia are the Canadian partners included in this initiative.

The former Washington state governor, Christine Gregoire, endorsed this kind of collaboration as a "game-changer" with global resonance:

"For the first time in history, we've been able to use the word 'cure' when it comes to cancer.

Not just prevent, not just treat, but cure. That is because together we're better. Together, we are

much more able to do the kind of research that will lead to those ultimate solutions" [44].

Regulatory Barriers

The presence of the international border limits the free mobility of scientists across the region [45]. Moreover, significant regulatory, social, technical and licensing barriers on the ground have been limiting cross-organizational access to data, resources, research and technology. These hindrances hamper the viability of partnerships among research organizations and technology companies, impeding the aggregation of data sets large enough to support machine learning and, in general, diminishing the innovation potential to develop treatments for cancer patients.

\section{Governance and Bottom-Up Engagement}

The Cascadia Innovation Corridor has been reported to bolster cooperation mostly at high-business levels, involving state-provincial levels of government and, at a lower engagement stage, local authorities [42]. The local communities are found to not be included in this process. Similarly, the CDDI is a public-private partnership with the strong involvement of multi-national companies (e.g., Microsoft) to pursue highly perceived societal value.

\subsubsection{Integrated Territorial Investments across Italy and Slovenia}

Three municipalities at the Italian-Slovenian border-Gorizia (IT), Nova Gorica (SLO) and Šmpeter-Vrtojba (SLO)-formed an EGTC in 2011, which then outlined a novel story of cross-cooperation with a sound impact on the territories, but also on the policy-making arenas, applying for the first (hereinto unique) integrated territorial investment in an EU cross-border region.

The European Grouping of Territorial Cooperation (EGTC) is a European legal instrument designed to facilitate and promote cross-border, transnational and interregional cooperation [46]. The EGTC-GO is a formal organization set up in Italy, but it gathers representatives from the three municipalities in its assembly. Furthermore, the EGTC-GO is equipped with six committees in order to address the following thematic groups: transportation, city planning, energy, health, culture and training and 
sport. Each committee gathers experts appointed by the three municipalities, including representatives from civil society, key-spoken persons, and delegates from business organizations.

Since its implementation in 2015, the EGTC-GO has been pursuing the objective to increase the quality of life of this cross-border area. The EGTC-GO drafted a strategic plan to drive development in the region upon three main trajectories:

- Promotion of the tourism heritage and cross-border natural resources;

- Cross-border health services;

- Cross-border public transportation.

Each trajectory has then been transformed into a real project with a sound impact in the region. The first objective is pursued through the construction of a cross-border natural park around the Isonzo-Soča River, enhancing the accessibility to the river and bolstering the tourism attractiveness of the area.

The second objective has prompted the project "Construction of a network of cross-border health services", which seeks to smooth accessibility to integrated services and health facilities involved in the cross-border region. This represents a very "hot topic" in cross-border public service delivery [47].

Finally, the third objective channels public expenditure on the creation of a railway link between the two national lines. This could smooth both freight movement and passenger mobility through the two countries, serving a wider region on both sides of the border.

Integrated Territorial Investments

In December 2015, the European Commission awarded a total grant of EUR 10 million to the three municipalities of Gorizia, Nova Gorica and Šempeter-Vrtojba to be managed as an Integrated Territorial Investment (ITI). The EU Commission appointed the EGTC-GO as the intermediate authority, with the responsibility to implement the ITI within the territory of the three municipalities. This represents a groundbreaking novelty for two main reasons: (I) this is a unique ITI case in EU applied in a cross-border region; and (II) this is the first European case of implementation of a common strategy by a sole beneficiary. The EGTC-GO is appointed as a sole entity-with territorial authority in the cross-border area-to encourage dialogue, coordinate the institutions involved in the projects, monitor the managing mechanisms and promote partnerships with stakeholders, including firms, local communities and public corporations.

The Isonzo-Soča project envisions forming a cross-border urban park based on the construction of a cross-border network of walking and cycling routes around the river. By allowing greater accessibility to the river from the three municipalities, the park will favor sustainable mobility among the local communities. Entrenching the relationship with the outdoor environment, the park will increase the attractiveness of the area for tourists and residents. The project is expected to build a cross-border cycle path that will link the two banks of the Isonzo-Soča River.

The health project pursues the goal of heightening the accessibility of health services, particularly in the fields of autism, mental health and physiological pregnancy. The cross-border region is endowed with excellent skills and expertise, especially in the first two domains. The project aims to create a single center for the booking of social and health services shared by Italian and Slovenian health facilities. Furthermore, the project will provide practical solutions for the inclusion of disadvantaged groups in order to integrate social assistance services.

Finally, the European Regional Development Fund (ERDF)-funded transportation project aims to tackle an infrastructure gap: a railway junction which would favor freight movement from Trieste harbor towards the southeast and smooth the mobility of passengers across the Italian and Slovenian border, as shown in Figure 1. 


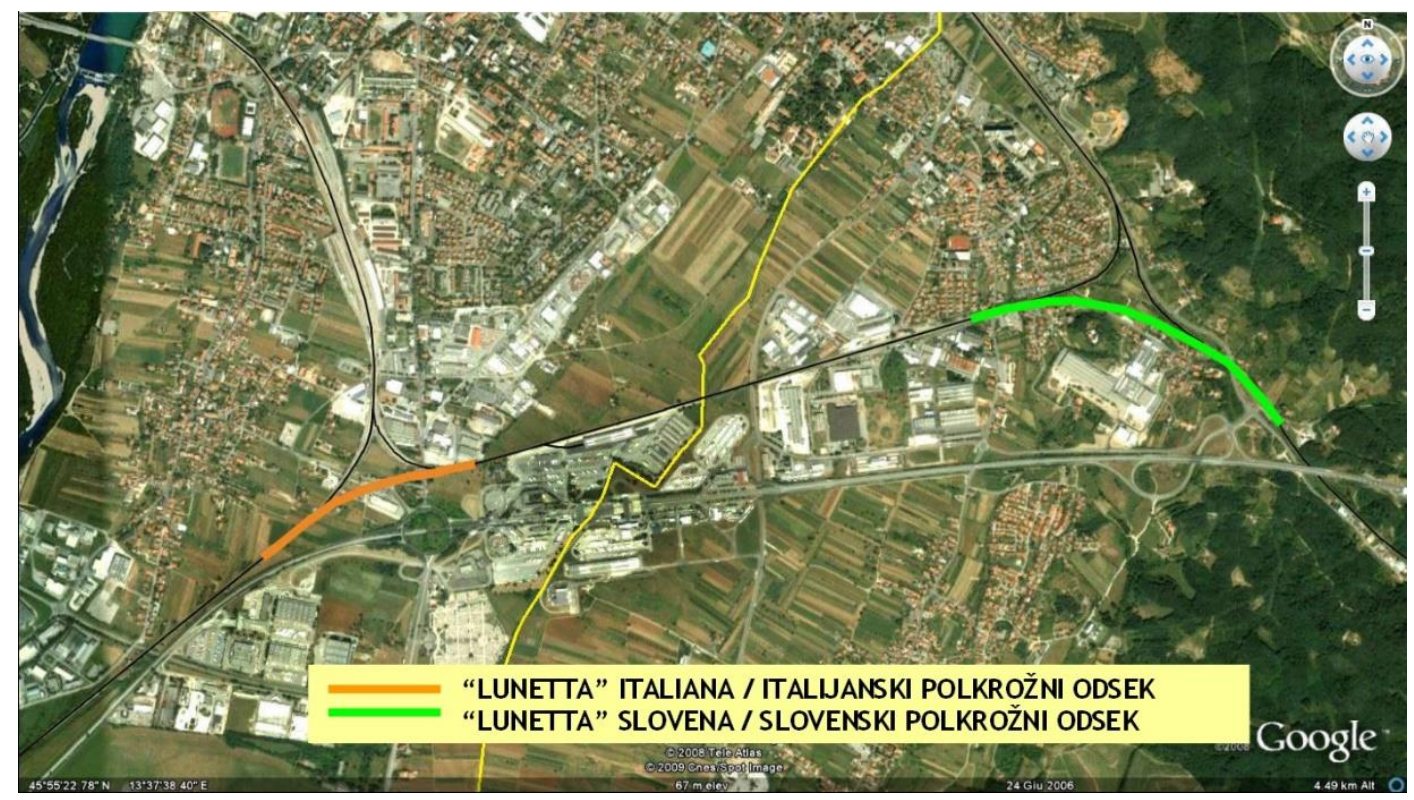

Figure 1. Projected railway junctions. Photo courtesy of: EGTC-GO.

Regulatory Barriers

The Slovenian legislation and the Italian legislation outline different laws for contracts, particularly in public tenders. The EGTC-GO being registered in the Italian territory, there was a problem with the Italian legislation, which does not allow foreign enterprises (in this case, Slovenian) to apply for tenders. The EGTC-GO then had to process a new platform (published in three different languages: Italian, Slovenian, and English) to manage the public tenders. Moreover, the EGTC-GO is legitimated to decide which legislation applies in each case for the realization of the infrastructures envisaged by the Isonzo-Soča project.

For the provision of services in the field of mental health, a legal regulatory framework from the two countries-Italy and Slovenia - was inspected by two task forces, one per country. The necessity and modality of clinical treatment for patients with disadvantaged (mental) capabilities represent sensitive issues in the two nations.

\section{Governance and Bottom-Up Engagement}

The EGTC is based on a public-public partnership, which collects experts in committees from civil society and business organizations. Still, the mechanism is entirely driven by public authorities. There seems to be a lack of involvement of private entities, which are likely not interested in the nature of the mobilized projects. In 2017, the three councils from each municipality convened in one single online meeting. This is probably the only activity to reach a large audience.

\subsubsection{The Alignment Between the R\&D Regional Agenda and a Cross-Border Regional Development Vision}

Aligning regional and local government levels in the panorama of modern public policies has been heralded [also] in cross-border regions under the "Multi-Level Institutional Approach" [48], where "horizontal linkage" represents cooperation among peers on the two sides of the border, while "vertical dynamics" refer to teamwork across different hierarchical government levels of the same nation. While this seems an obvious choice at the theoretical level, its implementation is not such a straightforward task. Under the smart specialization strategy framework, the regional authorities should also involve local government levels in designing their policy (e.g., entrepreneurial discovery process-EDP). Two reports from the EU Joint Research Center unveil that: (I) the majority of EU regions cooperate mostly with countrymate regions in R\&D policies [49], hinting at very low "horizontal 
linkage"; and (II) local authorities were invited to attend EDP processes by regional stakeholders [50], suggesting higher "vertical dynamics". This is why we consider the Spanish-Portuguese joint cross-border $\mathrm{S} 3$ as an exception to the rule.

The mission-oriented approach envisions a fine-tuned collaboration among different government levels. Therefore, we drew insights from two case studies to outline the potential application of MOA in cross-border regional development.

The Italian-Slovenian cross-border region is committed to enhance cross-border accessibility to health services, in line with Directive 2011/24/EU of the European Parliament. This project has been pursuing same objectives in line with the smart specialization strategy in Slovenia, which has been funding R\&D activities targeted at medical applications and quality of life. The Slovenian S3 sponsors the search for new substances and technologies in biomedicine combined with smart healthcare and personalized healthcare for the vulnerable population, including high-quality food and a clean environment. The cross-border regional project on health service implemented at the local level matches the alignment development trajectories on both sides of the border. In fact, Slovenia (which harnesses an S3 for its country) identified the sectors of biomedicine, diagnostics, medical informatics (eHealth) and bioinformatics as specialization areas for the programming period of 2014-2020. The neighboring Italian region, Friuli-Venezia Giulia, outlined "healthy living care services and products" as a specialization area, funding R\&D activities targeted at searching for new technologies and medical devices to improve patient care, diagnosis and treatment. Despite a strong alignment of economic interests and expertise between the two regional authorities in the life science sector as they implemented manifold programs (see the INTERREG-funded Trans2care project), there is no direct linkage with the projects happening in the cross-border region. This is probably due to the fact that the EGTC-GO in the region started to develop the project at the end of 2015, while the S3 design process concluded in the spring of 2016. However, the overall vision for the development of the cross-border areas seems very focused on infrastructure improvement. The regional economic development strategy is centered on the Life Science sector. At present, the EGTC-GO is driving the process to advance a joint candidature between Gorizia and Nova Gorica for the European Capital of Culture in 2025, which might give more "momentum" to the cross-border integration process [51].

The Danish-Swedish Øresund cross-border region features a historical tradition, which made this cross-border region a flagship of the European integration process. This region was strongly branded as a science hub for medicine and the life science sector, as it features a critical mass of research-intensive multinational companies, innovative small-medium enterprises (SME)s and world-class high education institutions with a focus on life science and ICT [52]. The landmark cross-border bridge, completed in 2000, propelled more integration between the two sides of the border, which, after ten years, seems to be lessening.

Nonetheless, this cross-border region maintains a first-tier role in life science supported by the "Medicon Valley" cluster with a global landscape. When scrutinizing the S3 of the three regional administrations involved in the Øresund cross-border region (see Table 3), we can see that the regional vision is still targeting the life science sector, but the two sides also share mutual interests in creative sectors, the food value chain and sustainable development.

The Øresund cross-border region embarked on manifold research projects blending actors from both sides of the border. This was the case of the R\&D project "ReproUnion", which pursued the tackling of infertility by bringing together universities, the health care sector and the Life Science industry. The vision of the cross-border region is well aligned with a shared R\&D agenda, blending innovation policies with local economic development. 
Table 3. Smart Specialization Strategy (S3) priorities as outlined by regional governments on both sides of the Øresund cross-border region. Adapted from the EYE@RIS3 web-platform. DK: Denmark; SE: Sweden.

\begin{tabular}{|c|c|c|}
\hline PRIORITY & REGION & DESCRIPTION \\
\hline \multirow{3}{*}{ Health } & Zealand (DK) & $\begin{array}{l}\text { The region is committed to enhance public-private collaboration within the } \\
\text { realm of its health innovation strategy to ensure the development and } \\
\text { implementation of health innovations, such as the construction of } \\
\text { super-hospitals, education of the workforce and better digital infrastructure. }\end{array}$ \\
\hline & $\begin{array}{l}\text { Capital Region } \\
\text { (DK) }\end{array}$ & $\begin{array}{l}\text { The Capital Region is committed to heightening the region's profile as a } \\
\text { knowledge region with a global resonance. Therefore, the Region supports } \\
\text { partnerships with leading researchers, companies and universities from both the } \\
\text { US and China by 2025. The focal points of these collaborations could include new } \\
\text { types of educational programs for health professionals and health entrepreneurs, } \\
\text { public-private innovation in new health technologies, development of the region } \\
\text { as a natural center for new knowledge-intensive health entrepreneurs and, } \\
\text { in particular, to gain maximum benefits from the European Spallation Source } \\
\text { (ESS) and Max IV as magnets for research and innovation in new materials and } \\
\text { life science. }\end{array}$ \\
\hline & $\begin{array}{l}\text { Skåne County } \\
\quad(\mathrm{SE})\end{array}$ & $\begin{array}{l}\text { The region seeks to: (1) boost development of new life science products, services, } \\
\text { e-health, business models and system solutions for preventive health measures; } \\
\text { (2) foster knowledge institutions that develop knowledge domains connected to } \\
\text { Big Science facilities ESS and MAX IV, in nanomaterials, life sciences and other } \\
\text { emerging fields. }\end{array}$ \\
\hline \multirow[b]{2}{*}{$\begin{array}{l}\text { Food } \\
\text { Production }\end{array}$} & Zealand (DK) & $\begin{array}{l}\text { The region sponsors innovation and efficiency improvement across food value } \\
\text { chains, including development of food processing technology, and increased } \\
\text { recycling of waste products into green energy. }\end{array}$ \\
\hline & $\begin{array}{l}\text { Skåne County } \\
\text { (SE) }\end{array}$ & $\begin{array}{l}\text { The regions seeks to boost food production in a circular and bio-based food } \\
\text { production system, food for quality of life and health, e.g., precision nutrition. } \\
\text { They seek to boost innovation in "related" sectors, including packaging and } \\
\text { logistics, FoodTech (e.g., precision farming), Internet of Things, } \\
\text { AI and 3D-printing. }\end{array}$ \\
\hline \multirow{2}{*}{$\begin{array}{l}\text { Creative } \\
\text { Growth }\end{array}$} & $\begin{array}{l}\text { Capital Region } \\
\text { (DK) }\end{array}$ & $\begin{array}{l}\text { The region seeks to leverage its key assets in areas that include high-quality } \\
\text { culinary services, entertainment, design, fashion industries and TV/movie } \\
\text { production to increase tourist revenues. }\end{array}$ \\
\hline & $\begin{array}{l}\text { Skåne County } \\
\text { (SE) }\end{array}$ & $\begin{array}{l}\text { The region is committed to support the development of its strong tech industry, } \\
\text { which has industrial leadership in artificial intelligence, Internet of Things, } 5 \mathrm{G} \text {, } \\
\text { connectivity, image recognition, big data and gaming, but also a strong creative } \\
\text { media industry, which is essential for digital transformation. }\end{array}$ \\
\hline \multirow[t]{2}{*}{$\begin{array}{c}\text { Sustainable } \\
\text { Development }\end{array}$} & $\begin{array}{l}\text { Capital Region } \\
\text { (DK) }\end{array}$ & $\begin{array}{l}\text { The Capital Region of Denmark will increase its focus on digital operations and } \\
\text { development in the public and private sectors and on the sharing economy to } \\
\text { ensure growth, welfare and increase its attractiveness to international visitors. } \\
\text { Therefore, the region will build a unified data infrastructure in close cooperation } \\
\text { with local authorities and other stakeholders: a comprehensive Wi-Fi network to } \\
\text { ensure that modern mobile and broadband coverage is established throughout } \\
\text { the region by 2020, making it more attractive to do business and settle in } \\
\text { the region. }\end{array}$ \\
\hline & $\begin{array}{l}\text { Skåne County } \\
\text { (SE) }\end{array}$ & $\begin{array}{l}\text { The region will mobilize knowledge, products, processes, services and systems at } \\
\text { the intersection between a broad range of technological areas to address cities' } \\
\text { sustainability challenges, such as energy, water, mobility and } \\
\text { information systems. }\end{array}$ \\
\hline
\end{tabular}

\section{Governance and Bottom-Up Engagement}

In the Øresund cross-border region, the governance scheme gathers a diverse set of actors institutionalized through the Øresund Committee [52], founded in 1993, with 12 membership entities: nine local municipalities (five Danish and four Swedish) and three regional bodies (two Danish and one Swedish) [53]. The committee has been working as a political platform, meeting place and builder of networks at all relevant levels (individuals, companies and (semi-)public organizations) [54] (p. 1024). The Medicon Valley Alliance is recognized as a very successful example of policy intervention 
stimulating cross-border collaboration, and it is hailed as a cross-border cluster organization [55]. A bi-national triple helix is ensured through the Øresund Business Council, the former Øresund University, the Øresund Direct and the Øresund Institute. Furthermore, manifold private initiatives corroborate with the cross-border regional governance scheme [52].

When the border controls were enforced (2015-2016) between the Danish and Swedish parts of the Øresund Bridge, the regional actors were actually ignored, since the decisions were based upon top-down hierarchical logic [56].

\section{Discussion}

This paper discusses the translation of the Mission-Oriented Approach (MOA) into a regional economic development strategy with the ambitious goal to revitalize the cross-border regions in the aftermath of the worldwide COVID-19 outbreak. This approach is designed to address specific problems under a clear direction within a time-bound framework with relevant societal value. The authors contend that the cross-border regions can be considered a suitable test bed for implementing an innovation policy approach, as MOA is. To convert MOA into a regional development strategy, we investigated three elements that need to be sized under a "place-based" approach [37]. The case studies illustrate real-world evidence to inform policy recommendations for further implementation in other cross-border regions. The results are summarized below (Table 4).

Table 4. Synoptic view of results in light of the evaluative framework.

\begin{tabular}{|c|c|c|c|}
\hline & $\begin{array}{l}\text { Italian-Slovenian Region } \\
\text { Gorizia-Nova Gorica }\end{array}$ & $\begin{array}{l}\text { US-Canadian } \\
\text { Cascadia }\end{array}$ & Swedish-Danish Øresund \\
\hline Policy Mix & $\begin{array}{l}\text { Cross-sectoral projects } \\
\text { implemented for local } \\
\text { economic development; } \\
\text { Transportation infrastructure } \\
\text { which connects the two sides } \\
\text { of the border (rail line } \\
\text { and cycleway); } \\
\text { Cooperation to provide } \\
\text { accessibility to health } \\
\text { services in the cross-border } \\
\text { region, in the same sectors } \\
\text { where the two regional and } \\
\text { national administrations } \\
\text { invest mutual interests for } \\
\text { regional development. }\end{array}$ & $\begin{array}{l}\text { Funding for a research } \\
\text { project concerning cancer } \\
\text { treatment (Cascadia Data } \\
\text { Discovery Initiative); } \\
\text { Cooperation among research } \\
\text { infrastructures which enable } \\
\text { data sharing; co-funded } \\
\text { research projects; } \\
\text { Branding the cross-border } \\
\text { region as a global tech hub } \\
\text { through the Cascadia } \\
\text { Innovation Corridor. }\end{array}$ & $\begin{array}{l}\text { Cluster organization } \\
\text { (Medicon Valley Alliance); } \\
\text { Flagship infrastructure (the } \\
\text { bridge over the Sund); } \\
\text { Cross-border education and } \\
\text { training activities; } \\
\text { Large cross-border R\&D } \\
\text { infrastructure (European } \\
\text { spallation Source and } \\
\text { Max IV). }\end{array}$ \\
\hline GOVERNANCE & $\begin{array}{l}\text { Public-public partnerships } \\
\text { governed through } \\
\text { the EGTC-GO. }\end{array}$ & $\begin{array}{l}\text { Public-private partnerships } \\
\text { governed by the secretariat } \\
\text { of the Cascadia } \\
\text { Innovation Corridor. }\end{array}$ & $\begin{array}{l}\text { Public-private partnership } \\
\text { mainly driven by } \\
\text { public bodies } \\
\text { (Øresund Committee). }\end{array}$ \\
\hline Bottom-Up Engagement & $\begin{array}{l}\text { Communities were not } \\
\text { involved. }\end{array}$ & None reported. & None reported. \\
\hline
\end{tabular}

The analysis showcases how the strategies rely on key competences in R\&D domains (oncology in the case of Cascadia, life science in the case of Øresund and mental health in the case of the Italian-Slovenian cross-border region), which support the need to tailor MOA under a "place-based" approach [37] to best leverage the competitive advantages of these regions [57].

The cases scrutinized pursue different perspectives: the Italy-Slovenia case relies on a regional development logic, while the US-Canadian one is more focused on research. If we consider implementation of the mission-oriented approach to guide development in cross-border regions, we should then glean insights from these two very different approaches. The case of Øresund looks 
like a mixed third way, as it best offers an alignment of the R\&D investment agenda with a vision for cross-border regional development.

As described in the mission-oriented narrative, these real case studies show that a regulatory framework is a burden to MOA implementation. This is reinforced due to the presence of international borders, which add complexity to innovation-led economic development [23].

Based on the results of this analysis, we can elaborate upon a few policy recommendations considering the three elements evaluated in MOA literature and scrutinized in the case study review.

Cross-border regions should select one main challenge to embrace through their strategy [58]. Holding this objective clear, they should pursue a clear direction outlining measurable targets and their strategy time-bound framework. A policy mix should then be designed in order to be cross-sectoral, multi-disciplinary and involve a variety of actors. From the case studies, a mixed approach is encouraged that combines the mobilization of physical capital (cross-border infrastructures and research facilities) and social capital (knowledge inherent of the territory and educational programs). It is then advised to boost innovation triggering both demand and supply, e.g., building research centers and infrastructure or funding research projects. Private involvement seems pivotal to allure more capital into the cross-border regions, but also to succeed in heightening the entrepreneurial profile in the tech sectors.

The branding of cross-border regions seems to be a common practice among the cases scrutinized. Most of them are committed to self-promote as hubs for innovation (Cascadia and Øresund) or as touristic attractions (all three cases).

The region between Italy and Slovenia can be distinguished for its institutional innovation, which should be considered in the policy makers' landscape as a viable strategy to harness EU resources for multiple projects.

Finally, the authors encourage the alignment of a research agenda with a territorial development vision that promotes not only economic targets, but also objectives concerning the quality of life in cross-border regions.

\section{Conclusions}

The current COVID-19 pandemic resulted in border closures around the world, severely affecting the quality of life in cross-border regions, which are often found to be at a disadvantage when compared to other regions in terms of employment, accessibility, social services and economic growth. This paper tackles the problem concerning post-pandemic economic recovery, social cohesion and environmental protection in border regions. In this regard, the mission-oriented approach is seen as a strategic scheme oriented towards very defined policy outcomes, the so-called "Grand Societal Challenges", which is proven to fit well with the needs of cross-border regional policies. The authors adopt this industrial policy concept into an economic development domain, to be tailored in cross-border regions under a "place-based" approach. Considering that the MOA has not yet been fully implemented in (cross-border) regional contexts, the paper evaluates the current practices underlining the suitability to adopt MOA principles in their cross-border regional policies. The cases scrutinized offer interesting practices to combine the research agenda and economic development strategies. The application of a "place-based" approach is ambivalent, since it tends to draw their strategies on R\&D assets, but community engagement seems very limited in all cases. None of the case investigated leveraged a significant bottom-up engagement, which, at the same time, opens new research avenues on the co-design of mission practices, but also hints at a weak understanding of the "place-based" approach when implementing the innovation policy. In this regard, policy makers and politicians are called to co-design a vision for their regions with their communities. This is a crucial aspect heralded in the MOA literature, but it is still neglected in practice.

The paper attempts to apply an industrial policy concept in a regional context. The evaluative power of the model has to be supported with more comparative studies when post-pandemic 
recovery strategies are implemented. The impacts of MOA should be scrutinized with more quantitative-based studies.

Author Contributions: F.C. developed the paper under the supervision of J.K.-P. who contributed providing insights and conclusions from the literature review, and adjusting the theoretical framework on the practical issues (case studies) she experienced during her scientific activities. All authors have read and agreed to the published version of the manuscript.

Funding: The project is funded under the program of the Minister of Science and Higher Education titled "Regional Initiative of Excellence" in 2019-2022, project number 018/RID/2018/19; amount of funding PLN 10,788,423.16.

Conflicts of Interest: The authors declare no conflict of interest.

\section{References}

1. Perkmann, M. Cross-border regions in Europe: Significance and drivers of regional cross-border co-operation. Eur. Urban. Reg. Stud. 2003, 10, 153-171. [CrossRef]

2. Böhm, H.; Drápela, E. Governance Forms within the EU, In: Central Europe Area in View of Current Geography. In Proceedings of the 23rd Central European Conference [online], Brno, Czechia, 8-9 October 2016; pp. 471-481.

3. Ergas, H. Does technology policy matter? In Technology and Global Industry: Companies and Nations in the World Economy; Guile, B.R., Brooks, H., Eds.; The National Academies Press: Washington, DC, USA, 1987; pp. 191-245.

4. Mazzucato, M. Mission-oriented innovation policies: Challenges and opportunities. Ind. Corp. Chang. 2018, 27, 803-815. [CrossRef]

5. Diercks, G.; Larsen, H.; Steward, F. Transformative innovation policy: Addressing variety in an emerging policy paradigm. Res. Policy 2019, 48, 880-894. [CrossRef]

6. Mazzucato, M. Mission-Oriented Research \& Innovation in the European Union; European Commission: Brussels, Belgium, 2018.

7. Foray, D. Smart specialization strategies as a case of mission-oriented policy-A case study on the emergence of new policy practices. Ind. Corp. Chang. 2018, 27, 817-832. [CrossRef]

8. Fagerberg, J. Mobilizing innovation for sustainability transitions: A comment on transformative innovation policy. Res. Policy 2018, 47, 1568-1576. [CrossRef]

9. Robinson, D.K.; Mazzucato, M. The evolution of mission-oriented policies: Exploring changing market creating policies in the US and European space sector. Res. Policy 2019, 48, 936-948. [CrossRef]

10. Rodrik, D. Industrial Policy for the Twenty-First Century. 2004. Available online: http://dx.doi.org/10.2139/ ssrn.617544 (accessed on 2 June 2020).

11. Foray, D.; David, P.A.; Hall, B. Smart specialisation-the concept. Knowl. Econ. Policy Brief 2009, 9, 100.

12. Mazzucato, M.; McPherson, M.; Hill, D. A Mission-Oriented approach to clean growth 2019. In Greater Manchester Independent Prosperity Review. Available online: https://www.ucl.ac.uk/bartlett/public-purpose/ publications/2019/sep/mission-oriented-approach-clean-growth (accessed on 2 June 2020).

13. Mazzucato, M. The Entrepreneurial State Debunking Public vs. Private Sector Myths; Anthem Press: London, UK, 2018.

14. Mazzucato, M.; Kattel, R.; Ryan-Collins, J. Challenge-Driven Innovation Policy: Towards a New Policy Toolkit. J. Ind. Compet. Trade 2020, 20, 1-17. [CrossRef]

15. Hekkert, M.; Janssen, M.J.; Wesseling, J.H.; Negro, S.O. Mission-oriented innovation systems. Environ. Innov. Soc. Transit. 2020, 34, 76-79. [CrossRef]

16. Fisher, R.; Chicot, J.; Domini, A.; Misojic, M.; Polt, W.; Turk, A.; Goetheer, A. Mission-Oriented Research and Innovation: Assessing the Impact of a Mission-Oriented Research and Innovation Approach; European Commission: Brussels, Belgium, 2018.

17. Karo, E. Mission-oriented innovation policies and bureaucracies in East Asia. Ind. Corp. Chang. 2018, 27, 867-881. [CrossRef]

18. Foray, D.; Mowery, D.C.; Nelson, R.R. Public R\&D and social challenges: What lessons from mission R\&D programs? Res. Policy 2012, 41, 1697-1702.

19. Deleidi, M.; Mazzucato, M. Mission-Oriented Innovation Policies: A Theoretical and Empirical Assessment for the Us Economy (No. 0248); Department of Economics-University Roma Tre: Rome, Italy, 2019. 
20. Böhm, H.; Opiola, W. Czech-Polish cross-border (non)co-operation in the field of labour market: Why does it seem to be un-de-bordered? Sustainability 2019, 11, 2855. [CrossRef]

21. Cappellano, F.; Makkonen, T. Cross-border regional innovation ecosystems: The role of non-profit organizations in cross-border cooperation at the US-Mexico border. GeoJournal 2019, 1-14. [CrossRef]

22. Cappellano, F.; Rizzo, A. Economic drivers in cross-border regional innovation systems. Reg. Stud. Reg. Sci. 2019, 6, 460-468. [CrossRef]

23. Cappellano, F.; Makkonen, T. The Proximity Puzzle in Cross-Border Regions. Plan. Pract. Res. 2020, 35, 283-301. [CrossRef]

24. Moodysson, J.; Jonsson, O. Knowledge collaboration and proximity: The spatial organization of biotech innovation projects. Eur. Urban Reg. Stud. 2007, 14, 115-131. [CrossRef]

25. Makkonen, T.; Rohde, S. Cross-border regional innovation systems: Conceptual backgrounds, empirical evidence and policy implications. Eur. Plan. Stud. 2016, 24, 1623-1642. [CrossRef]

26. Makkonen, T.; Weidenfeld, A.; Williams, A.M. Cross-border regional innovation system integration: An analytical framework. Tijdschr. Voor Econ. Soc. Geogr. 2017, 108, 805-820. [CrossRef]

27. Makkonen, T.; Williams, A.M.; Weidenfeld, A.; Kaisto, V. Cross-border knowledge transfer and innovation in the European neighbourhood: Tourism cooperation at the Finnish-Russian border. Tour. Manag. 2018, 68, 140-151. [CrossRef]

28. Kurowska-Pysz, J.; Szczepańska-Woszczyna, K. The analysis of the determinants of sustainable cross-border cooperation and recommendations on its harmonization. Sustainability 2017, 9, 2226. [CrossRef]

29. Kurowska-Pysz, J. Opportunities for cross-border entrepreneurship development in a cluster model exemplified by the Polish-Czech border region. Sustainability 2016, 8, 230. [CrossRef]

30. Sohn, C. Modelling cross-border integration: The role of borders as a resource. Geopolitics 2014, 19, 587-608. [CrossRef]

31. OECD. Regions and Innovation: Collaborating Across Borders; OECD: Paris, France, 2013.

32. Lundquist, K.J.; Trippl, M. Distance, proximity and types of cross-border innovation systems: A conceptual analysis. Reg. Stud. 2013, 47, 450-460. [CrossRef]

33. Oliveira, E. Constructing regional advantage in branding the cross-border Euroregion Galicia-northern Portugal. Reg. Stud. Reg. Sci. 2015, 2, 341-349. [CrossRef]

34. Kurowska-Pysz, J.; Szczepańska-Woszczyna, K.; Štverková, H.; Kašík, J. The catalysts of cross-border cooperation development in euroregions. Pol. J. Manag. Stud. 2018, 18, 180-193. [CrossRef]

35. ESPON. State of the European Territory/Interim Report; ESPON EGTC: Luxemburg, 2019.

36. Kurowska-Pysz, J. The Circumstances of Knowledge Transfer within the Scope of the Cross-Border Czech-Polish Projects 2014-2020. Forum. Sci. Oeconomia 2015, 3, 31-43.

37. Barca, F.; McCann, P.; Rodríguez-Pose, A. The case for regional development intervention: Place-based versus place-neutral approaches. J. Reg. Sci. 2012, 52, 134-152. [CrossRef]

38. Magro, E.; Wilson, J.R. Policy-mix evaluation: Governance challenges from new place-based innovation policies. Res. Policy 2018, 48, 103612. [CrossRef]

39. Petrella, A. Fostering Innovation Through Public Procurement: Rationale, Implementation and Best Practices in Italy and Europe. 2013. Available online: https://www.bancaditalia.it/pubblicazioni/altri-atti-convegni/ 2014-innovazione-italia/Petrella.pdf (accessed on 2 June 2020).

40. Edquist, C.; Zabala-Iturriagagoitia, J.M. Functional Procurement for Innovation, Welfare and the Environment: A Mission-Oriented Approac (No. 2020/1); Lund University, CIRCLE-Center for Innovation, Research and Competences in the Learning Economy: Lund, Sweden, 2020.

41. British Columbia-Washington MOU. 2016. Available online: https://news.gov.bc.ca/files/BC_WA_ Innovation_MOU.pdf (accessed on 2 June 2020).

42. Cappellano, F.; Richardson, K.; Trautman, L. Cross border regional planning: Insights from Cascadia. Int. Plan. Stud. 2020, 35, 1-16. [CrossRef]

43. Cappellano; Francesco; Border Policy Research Institute; Western Washington University; Borders in Globalization; University of Victoria. Cross Border Innovation Economies: The Cascadia Innovation Corridor Case; Border Policy Research Institute Publications: Bellingham, WA, USA, 2016. Available online: https: //cedar.wwu.edu/bpri_publications/116 (accessed on 2 June 2020).

44. Microsoft. Available online: https://news.microsoft.com/on-the-issues/2019/10/01/cascadia-innovationcorridor-conference/ (accessed on 5 April 2020). 
45. Richardson, K.E. Knowledge Borders: Temporary Labor Mobility and the Canada-US Border Region; Edward Elgar Publishing: Chelthenham, UK, 2017.

46. European Commission. Available online: https://ec.europa.eu/regional_policy/it/policy/cooperation/ european-territorial/egtc/ (accessed on 5 June 2020).

47. Böhm, H.; Kurowska-Pysz, J. Can Cross-Border Healthcare Be Sustainable? An Example from the Czech-Austrian Borderland. Sustainability 2019, 11, 6980. [CrossRef]

48. Van den Broek, J.; Smulders, H. Institutional hindrances in cross-border regional innovation systems. Reg. Stud. Reg. Sci. 2015, 2, 116-122. [CrossRef]

49. Uyarra, E.; Marzocchi, C.; Sorvik, J. How outward looking is smart specialisation? Rationales, drivers and barriers. Eur. Plan. Stud. 2018, 26, 2344-2363. [CrossRef]

50. Marinelli, E.; Perianez-Forte, I. Smart Specialisation at Work: The Entrepreneurial Discovery as a Continuous Process; European Union: Luxemburg, 2017.

51. Suchacek, J. The Benefit of Failure: On the Development of Ostrava's Culture. Sustainability 2019, 11, 2592. [CrossRef]

52. Nauwelaers, C.; Maguire, K.; Marsan, G.A. The Case of Oresund (Denmark-Sweden)-Regions and Innovation: Collaborating Across Borders. 2013. Available online: https://ideas.repec.org/p/oec/govaab/2013-21-en.html (accessed on 2 June 2020).

53. Olesen, K.; Metzger, J. The region is dead, long live the region. The Øresund Region 15 years after the bridge. In Situated Practices of Strategic Planning-An International Perspective; Albrechts, L., Balducci, A., Hillier, J., Eds.; Routledge: Oxon, UK, 2017; pp. 67-83.

54. Hospers, G.H. Borders, bridges and branding: The transformation of the Øresund region into an imagined space. Eur. Plan. Stud. 2006, 14, 1015-1033. [CrossRef]

55. Hansen, T. Bridging regional innovation: Cross-border collaboration in the Øresund Region. Geogr. Tidsskr. Dan. J. Geogr. 2013, 113, 25-38. [CrossRef]

56. Madsen, P.W. The Dynamics of Cross-Border Regional Innovation Systems. A Study on the Effects of the Border Control on the Øresund Region. Master's Thesis, Lund University, Lund, Sweden, June 2017.

57. Suchacek, J.; Sed'a, P.; Friedrich, V. Size and Regional Varieties of Communal Marketing in the Czech Republic. Pol. J. Manag. Stud. 2017, 15, 262-272. [CrossRef]

58. Suchacek, J.; Walancik, M.; Wróblewski, L.; Urminský, J.; Drastichová, M.; Šotkovský, I. Management of Municipal Development of Euroregion Beskydy in Poland and Czechia. Pol. J. Manag. Stud. 2018, 18, 365-378. [CrossRef] 